\title{
"La sociedad presente como materia novelable»
}

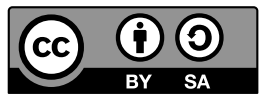

El título del presente número temático corresponde al discurso que el 7 de febrero de 1897 leyó Benito Pérez Galdós en el acto de su recepción pública en la Real Academia Española. Con ocasión del centenario de la muerte del autor canario, nos hemos apropiado de dicho título para dedicar este volumen a lo que se podría resumir como el modus scribendi galdosiano, que convirtió al mayor testigo del Madrid decimonónico en uno de los novelistas más aclamados y prolíficos en lengua española.

No obstante, en el marco de la literatura realista y naturalista europea, tan solo recientemente se le ha venido admitiendo a la novela galdosiana una significación, envergadura y, finalmente, un relieve equiparable a los que siempre había tenido en las letras hispánicas. Fredric Jameson le dedica un capítulo en su estudio The Antinomies of Realism ${ }^{1}$ - galardonado con el Premio Truman Capote de crítica literaria-, advirtiendo que la ausencia de Pérez Galdós en la lista convencional de los grandes realistas del siglo XIX, además de ser «un crimen», asimismo limita y deforma considerablemente la imagen que la crítica e historia literarias se habían forjado sobre el género, sus posibilidades y dimensiones. Nos atreveríamos a decir que tal posición es complementaria a la defendida por Jesús G. Maestro², quien se opone a la interpretación zoliana de la novela española de la segunda mitad del siglo XIX, constatando que el llamado Naturalismo está presente en la literatura española desde el Cantar de Mio Cid, siendo sus más ilustres antecedentes la novela picaresca y El Quijote. Lo más curioso, pero de suma relevancia, es el hecho de que la misma idea hubiera sido desplegada por el propio Pérez Galdós en su prólogo a la edición del 1900 de La regenta de Clarín, donde comparó la trayectoria de lo que en su época vino a definirse como Naturalismo, con la Corriente del Golfo. La novela toma su origen en el Siglo de Oro español para pasar, en el siglo XVIII, por Inglaterra, la cuna de la Ilustración y de la novela moderna, y en el siglo XIX por Francia, desde donde, a mediados del mismo siglo, habiéndose movido por el mapa de Europa en

1 Fredric Jameson (2013): The Antinomies of Realism. London/Brooklyn: Verso, 95.

2 Jesús G. Maestro (2017): Crítica de la razón literaria. Vigo: Editorial Academia del Hispanismo. 
el sentido de reloj, igual que dicha corriente, no llegaba sino que terminaba volviendo al territorio del que había surgido.

Pero fuerza es reconocer del Naturalismo que acá volvía como una corriente circular parecida al gulf stream, traía más calor y menos delicadeza y gracia. El nuestro, la corriente inicial, encarnaba la realidad en el cuerpo y rostro de un humorismo que era quizás la forma más genial de nuestra raza. Al volver a casa la onda, venía radicalmente desfigurada: en el paso por Albión habíanle arrebatado la socarronería española, que fácilmente convirtieron en bumour inglés las manos hábiles de Fielding, Dickens y Thackeray, y despojado de aquella característica elemental, el naturalismo cambió de fisonomía en manos francesas: lo que perdió en gracia y donosura, lo ganó en fuerza analítica y en extensión, aplicándose a estados psicológicos que no encajan fácilmente en la forma picaresca. Recibimos, pues, con mermas y adiciones (y no nos asustemos del símil comercial) la mercancía que habíamos exportado, y casi desconocíamos la sangre nuestra y el aliento del alma española que aquel ser literario conservaba después de las alteraciones ocasionadas por sus viajes. En resumidas cuentas: Francia, con su poder incontrastable, nos imponía una reforma de nuestra propia obra, sin saber que era nuestra; aceptámosla nosotros restaurando el Naturalismo y devolviéndole lo que le habían quitado, el humorismo, y empleando este en las formas narrativa y descriptiva conforme a la tradición cervantesca. ${ }^{3}$

Estos han sido nuestros dos puntos de partida al convocar y componer el presente volumen en homenaje al gran novelista: aportar estudios críticos novedosos sobre su obra e insistir en que esta ocupa un lugar imprescindible en un marco mucho más amplio del que le fue asignado por la crítica incluso en el siglo XX. Por lo tanto, queríamos llamar la atención también sobre estudios relativos a las obras y a los autores de prosa narrativa que, en cualquier época, directa o indirectamente compartieran las inquietudes, los anhelos y la perspicacia de Pérez Galdós: observación, cuadro, crítica o sátira de la sociedad contemporánea, acompañados de un compromiso humanista e ilustrado para con ella.

3 Benito Pérez Galdós (2000 [1900]): «Prólogo». En: Leopoldo. Alas, «Clarín»: La regenta. Alicante: Biblioteca Virtual Miguel de Cervantes, X-XI. 
El volumen lo encabeza un estudio que retrata la trayectoria de la novela naturalista española casi del mismo modo que la percibía Pérez Galdós. Tomás Albaladejo escribe sobre la evocación de don Quijote en la novela Bailén, una de las series históricas de los Episodios Nacionales. Se trata de la transducción literaria basada en la lectura galdosiana de la novela de Cervantes, llevada a cabo desde la perspectiva del autor y del protagonista, narrador en primera persona. El artículo también evoca a Napoleón Bonaparte. Igualmente hay referencias al levantamiento del pueblo español en Madrid el 2 de mayo de 1808 contra el ejército francés y a los fusilamientos de españoles por los pelotones de fusilamiento franceses el 3 de mayo de 1808 y antes de la batalla de Bailén. Las evocaciones mencionadas se analizan desde el enfoque del perspectivismo y se explican como una polarización dialéctica entre los elementos literarios e históricos. La interpretación de don Quijote en la novela le sirve a Tomás Albaladejo como punto de partida en sus reflexiones sobre el papel de la historia y la ficción en la novela.

El artículo de Susanna Regazzoni orienta la mirada hacia una materia novelable más reciente. Su análisis de tres relatos de la segunda mitad del siglo XX, convergentes en cuanto al motivo referencial -el cuerpo embalsamado de la difunta esposa de Perón, Evita-, y complementarios en la puesta en evidencia del proceso de mitificación de un personaje histórico, por un lado, y del principio de desmitificación del mismo por la literatura por el otro, señala cómo el relato literario supera a la Historia en plasmar las verdades del antagonismo ideológico y cultural en la historia, en el caso concreto, la argentina.

A la línea de los estudios galdosianos se suma el escrito por Vladimir Karanović, quien parte de la teoría de Michel Foucault para observar el tema de la prostitución, inmanente a la novelística de Pérez Galdós, en tanto que conducta social o sexual desviada. En tres novelas, La desheredada, Fortunata y Jacinta y Nazarín, analiza la disciplina corporal, la opresión social y sexual de la mujer española, la vigilancia panóptica masculina y la imagen de la mujer según los postulados de la sociedad burguesa durante el siglo XIX, y termina comprobando que el tema de la prostitución y la mujer que la protagoniza, sirvió a Pérez Galdós para elaborar y difundir su crítica dirigida a la sociedad española de su tiempo.

Una parte importante del volumen la conforman los estudios comparativos dedicados a la recepción de la obra y la técnica narrativa galdosianas tanto por parte de sus coetáneos como por la de autores actuales. Rastreando las huellas del novelista en la más reciente actualidad, Laura Ventura propone un 
análisis innovador de la última novela de la escritora e historiadora Almudena Grandes, La madre de Frankenstein (2020), para demostrar cómo confluyen en su obra dos procedimientos que la convierten en heredera de Benito Pérez Galdós. Daniel González Gallego, por su parte, explora la producción literaria de Eva Canel para analizar de qué manera esta escritora y periodista asturiana asentada en Cuba, aplicó, desde el otro lado del Atlántico, el modus scribendi y la óptica galdosianos a un contexto específico: el periodo colonial y la crisis finisecular española. Finalmente, el estudio de M. Carmen Domínguez Gutiérrez compagina el enfoque sociohistórico con el biobibliográfico y abarca la recepción de la obra galdosiana tanto en España como en Hispanoamérica, contrastando la perspectiva más bien adversa de la generación contemporánea y la inmediatamente posterior a su época con la de los intelectuales republicanos exiliados que restituyeron la centralidad que le correspondía al escritor en la estirpe de los máximos exponentes de literatura en lengua española.

En esta misma línea de consideración de los méritos literarios de Pérez Galdós, se inscribe el texto que, a modo de ensayo, cierra el volumen temático: la contribución de Matías Escalera Cordero intitulada «La novela en el tranvía: los orígenes del realismo dinámico, crítico y cervantino de Galdós». El autor propone una reflexión desde el punto de vista de novelista, para discurrir sobre las herramientas y abordajes narrativos que utilizó el autor decimonónico. La crítica literaria modernista o de la Generación del 98 y luego, novelistas del siglo XX, como Juan Benet o más recientemente Javier Cercas, quisieron hacernos creer que Pérez Galdós se inspiraba en elementos de carácter simbólico o fantástico (que cambió radicalmente las bases del arte europeo occidental) tan solo al final de su trayectoria literaria. Este ensayo presenta el empleo de elementos no realistas ya mucho antes, esto es, antes de las novelas El amigo Manso, Tristana o Nazarín, La desheredada o Ángel Guerra, y específicamente en el cuento La novela en el tranvía, donde ya encontramos elementos como la fragmentación y multiplicación de la voz narrativa.

Ignac Fock, Branka Kalenić Ramšak, Maja Šabec 